\title{
Cancer stem cells and hypoxia-inducible factors (Review)
}

\author{
WEI-WEI TONG, GUANG-HUI TONG and YONG LIU
}

\author{
Department of Laboratory Medicine, Shengjing Affiliated Hospital, \\ China Medical University, Shenyang, Liaoning 110004, P.R. China
}

Received February 8, 2018; Accepted May 14, 2018

DOI: $10.3892 /$ ijo.2018.4417

\begin{abstract}
Cancer stem cells (CSCs), also known as tumorinitiating cells, are a subpopulation of tumor cells that exhibit properties similar to those of normal stem cells. Oxygen is an important regulator of cellular metabolism; hypoxia-inducible factors (HIFs) mediate metabolic switches in cells in hypoxic environments. Hypoxia clearly has the potential to exert a significant effect on the maintenance and evolution of CSCs. Both HIF-1 $\alpha$ and HIF-2 $\alpha$ may contribute to the regulation of cellular adaptation to hypoxia and resistance to cancer therapies. This review provides an overview of the roles of HIFs in CSCs. HIF-1 $\alpha$ and HIF-2 $\alpha$ have significant prognostic and predictive value in the clinic and the concept of personalized medicine should be applied in designing clinical trials for HIF inhibitors.
\end{abstract}

\section{Contents}

1. Brief history of CSCs

2. Origin of CSCs

3. Properties of CSCs

4. The roles of HIFs in cancer

5. The roles of HIFs in CSCs

6. Future perspectives

\section{Brief history of CSCs}

The original hypothesis of CSCs was proposed several decades ago (Fig. 1). Virchow first proposed that some tumors may arise from embryo-like cells and that cancer cells have properties reminiscent of stem cells reported in 1855 (1). In 1937, Furth and Kahn confirmed that a single leukemic cell from a mouse tumor could initiate a new tumor in a recipient mouse (2). Southam and Brunschwig harvested recurrent

Correspondence to: Dr Yong Liu, Department of Laboratory Medicine, Shengjing Affiliated Hospital, China Medical University, 36 Sanhao Street, Heping, Shenyang, Liaoning 110004, P.R. China E-mail: liuy@sj-hospital.org

Key words: cancer stem cells, hypoxia-inducible factors, ABCG2 cancer cells from patients and demonstrated the differential tumor-forming ability of these cells in 1961 (3). In 1977, Hamburger and Salmon found that tumor stem cell colonies arising from different types of cancer have differing growth characteristics and colony morphology (4). Lapidot et al (5) defined a new leukaemia-initiating cell from human acute myeloid leukemia (AML) by using a mouse model in 1994. Bonnet and Dick first demonstrated the existence of CSCs in AML in 1997 (6). This is the most notable and definitive evidence regarding the existence of CSCs. Following research into leukemia, the first CSCs identified in solid tumors were demonstrated in breast cancer by Al-Hajj and colleagues in 2003 (7). Since then, numerous studies have provided evidence of the existence of CSCs in solid tumors of a number of tissue types, including the brain (8), breast (9) and prostate (10).

\section{Origin of CSCs}

According to the somatic stem cell hypothesis, mutations or chromosomal rearrangements in dormant stem cells present in organs may induce the formation of CSCs (11). It has been demonstrated that the implantation of embryonic stem cells or the induction of pluripotent stem cells in mice results in cancer (12). Another view on the origin of CSCs is that cancer cells with genetic instability may generate CSCs (13). Cancer cells transfected with Oct3/4, Sox2, Klf4 and c-Myc have been reported to transform into CSCs (14).

In most scenarios, CSC subpopulations have emerged following the accumulation of epigenetic and/or genetic alterations in normal stem cells or cancer cells. However, in 2013, Wang et al (15) hypothesized that CSCs develop de novo from the misplaced somatic stem cells and proposed a new theory of carcinogenesis; the stem cell misplacement theory. This theory stated that misplaced epithelial stem cells, which reach the wrong tissue stroma by accident undergo malignant transformation and become CSCs.

\section{Properties of CSCs}

CSCs, also known as tumor-initiating cells or tumor-propagating cells are a subpopulation of tumor cells that demonstrate properties similar to normal stem cells (16). Tumor-initiating cells may better describe these cells; however, we have referred to these cells as CSCs in this review. At the 2006 meeting of the American Association for Cancer Research, Reya et al (17) proposed the definition of a cancer stem cell as a cell within 
a tumor that possesses the capacity to self-renew and produce the heterogeneous lineages of cancer cells that comprise the tumor.

Tumorigenicity and self-renewal. The core definition of CSCs comprises their ability to induce tumor formation (17). Tumorigenicity is defined as the capacity of a cell population inoculated into an animal model to produce a tumor by proliferation (18). The process of tumorigencity has been long known to resemble organogenesis; most tumors are heterogeneous, containing many cells that vary phenotypically and functionally (19). The current hypothesis is that tumor growth and progression are driven by minority populations of tumorigenic cells, and that other cancer cells have little or no capacity to contribute to tumor growth (20). The proportion of tumorigenic cells in cancer is very low. For example, both in the study by O'Brien et al (21) and Hope et al (22), only one cell in $10^{4}-10^{6}$ unsorted human cancer cells was able to generate a tumor following xenotransplantation into immunosuppressed mice. In the study by Xia et al (23), they also found that the tumorigenic cell fraction comprised only $0.28 \%$ of Lewis lung carcinoma cells.

Two main approaches have been used to identify tumorigenic cells in published studies: One method is termed 'spheroid colony formation; and is considered the most appropriate in vitro assay to detect the malignant transformation of cells (25), and the other one is an in vivo method involving implantation of tumorigenic cells in immunodeficient mice (26).

The hallmark of stem cells is their dual ability to self-renew and to generate multiple cell lineages with more differentiated characteristics (26). Self-renewal is the ability of a CSC to sustain itself and continue to give rise to cells with equal abilities of tumorigenicity (27). CSCs can self-renew through asymmetric cell division in which one daughter cell possesses stem cell properties (28). Prior to asymmetric division, unequally distributed cellular components are differentially enriched at either the apical or basal pole, in which the mitotic spindle apparatus and centrosomes are unequally aligned (29).

Drug resistance. Anticancer drugs have been applied alone or in combination to prolong life or to alleviate the symptoms of cancer for decades $(30,31)$. However, these drugs have failed to completely eradicate cancers. Multidrug resistance (MDR) plays an important role in preventing drug absorption (32). Various factors can contribute to MDR, including the existence of CSCs (33). CSCs possess multiple mechanisms of drug resistance: A high expression of $\mathrm{ABC}$ transporters and anti-apoptotic factors, and the maintenance of a quiescent state to avoid the induction of apoptosis (34). The ABC transporter family acts by pumping drugs into the extracellular domain (35). To date, 49 human $\mathrm{ABC}$ genes have been identified and are clustered in seven subfamilies (ABCA-ABCG) (36). There are three major transporters correlated with MDR, including P-glycoprotein (MDR1/ABCB1), MDR-associated protein $(\mathrm{MRP} / \mathrm{ABCC} 1)$ and breast cancer resistance protein (BCRP/ABCG2) (37).

P-glycoprotein (ABCB1). P-glycoprotein (P-gp) is a $170 \mathrm{kDa}$ phosphoglycoprotein constituting two transmembrane domains and two cytosolic nucleotide-binding domains (Fig. 2) (38). P-gp overexpression is related to negative clinical outcomes, including treatment failure, relapse and survival. An increased P-gp expression has been observed in breast tumor biopsies treated with conventional chemotherapy (39). In a previous study on AML, the relapse rates were associated with elevated P-gp expression levels (40). A similar observation was reported in a study on multiple myeloma, in which $6 \%$ of patients expressed P-gp at diagnosis, and $>43 \%$ of patients exhibited overexpressed P-gp following treatment (41). The patients with osteosarcoma that did not overexpress P-gp had significantly better relapsefree rates and improved survival rates of 5 to 14 years (42). $\mathrm{P}-\mathrm{gp}$ plays a significant role in transporting a diverse array of molecules, including anionic, and neutrally charged drugs and toxins (43-45).

$M R P / A B C C 1 . \mathrm{MRP} 1 / \mathrm{ABCC} 1$ was the first gene to be identified in the ABCC subfamily and was cloned from an MDR small cell lung cancer cell (46). Numerous studies have demonstrated the upregulation of MRP1 in a variety of solid tumors, such as those of the lung, breast and prostate (47-49). MRP1 is potentially an important target for reversing chemotherapy resistance in many cancers (50).

Breast cancer resistance protein (BCRP/ABCG2). Human BCRP is encoded by the ABCG2 gene which is located on chromosome $4 \mathrm{q} 22$ (51). ABCG2 is the second member of subfamily $G$ within the large human $A B C$ transporter superfamily (49). BCRP is believed to exhibit important physiological and pathophysiological functions in tissues and is involved in cellular protection and in mediating the homeostasis of physiological substrates (52).

\section{The roles of HIFs in cancer}

Hypoxia is an important factor that affects clinical outcomes by promoting genetic instability, tumor cell metastasis and invasiveness (53). The HIF protein is a heterodimeric complex formed by an oxygen-dependent $\alpha$ subunit and an oxygeninsensitive $\beta$ subunit (53). The three HIF $\alpha$ subunits (HIF-1 $\alpha$, HIF- $2 \alpha$ and HIF-3 $\alpha$ ) with a HIF- $1 \beta$ subunit act as key mediators of cellular adaptation to low oxygen (54). The carboxy-terminal domain of HIF- $1 \alpha$ and HIF- $2 \alpha$ consists of domains that regulate its stability (the oxygen-dependent degradation domain, ODD) and transcriptional activity (two transactivation domains (TADs), N-TAD and C-TAD (Fig. 3) (55). Furthermore, both the $\mathrm{C}$ - and $\mathrm{N}$-termini of the $\alpha$ subunits have nuclear localization signals (N-NLS and C-NLS, respectively) that direct them to the nucleus (Fig. 3) (56). The stability of HIF- $1 \alpha$ and HIF-2 $\alpha$ is regulated by oxygen tension (57). HIF- $1 \alpha$ and HIF-2 $\alpha$ have been extensively studied and are ubiquitously expressed in normal tissue (58). C-TAD regulates most hypoxia-induced genes, although a subset of genes depended solely on N-TAD initiation, and N-TAD contributes to target gene specificity of HIF-1 $\alpha$ and HIF-2 $\alpha$ (59). An increased HIF-1 $\alpha$ or HIF- $2 \alpha$ expression has been observed in many types of cancer, such as breast (60), colon (61), lung (62), pancreatic (63) and ovarian cancers (65) (Figs. 4 and 5). Upon exposure of the cells to hypoxia, the HIF $\alpha$ subunits accumulate in the 
1855: Virchow

'embryonal-rest hypothesis' of tumour formation

1994: Lapidot

Cancer initiating/cancer stem cells in acute myeloid leukaemia

2003: Al-Hajj

CSCs in a solid cancer (breast cancer)

\section{7: O'Brien}

CD133 as a marker for CSCs
1977: Hamburger and Salmon

the entire population of tumour cells

might arise from a few so-called

'cancer stem cells'

1997: Bonnet and Dick

Leukemic stem cells

\section{4: Singh}

Self renewal properties of brain cancer

stem cell

Figure 1. The timeline of cancer stem cell research.

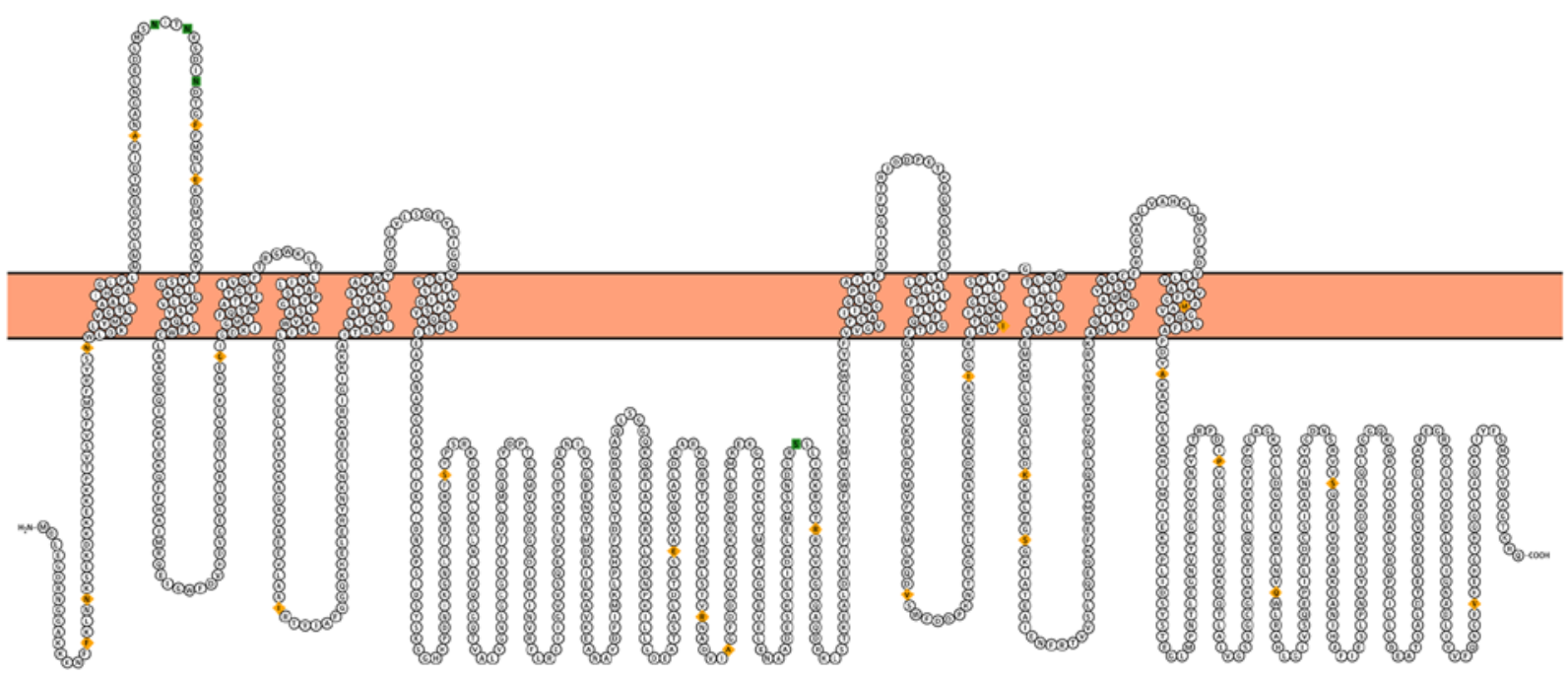

Figure 2. Ideograph of ABCB1 protein generated using Peptide Atlas (https://db.systemsbiology.net/sbeams/cgi/PeptideAtlas/Search). P-glycoprotein (P-gp) is a $170 \mathrm{kDa}$ phosphoglycoprotein constituting two transmembrane domains and two cytosolic nucleotide-binding domains.
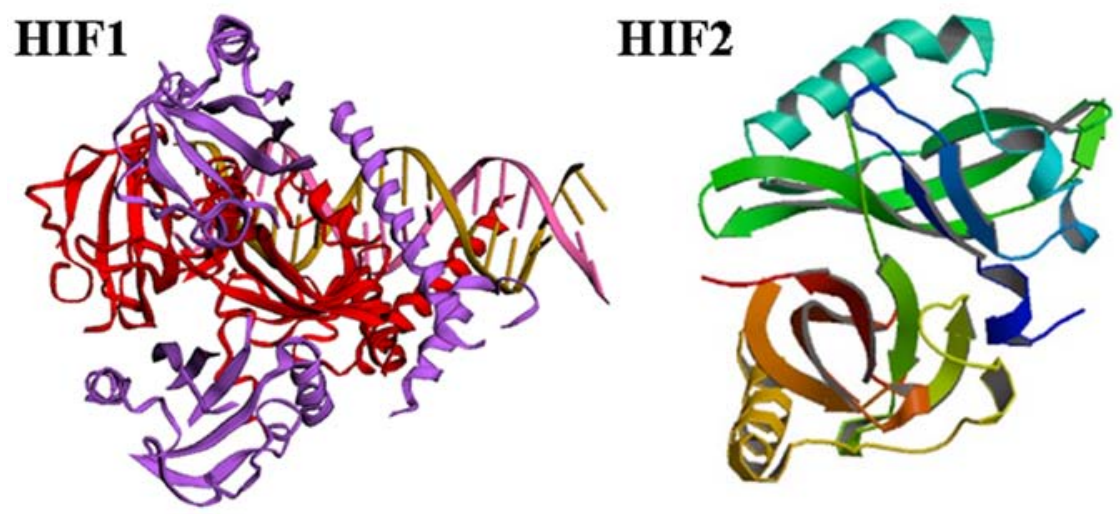

Figure 3. Structure of HIF-1 $\alpha$ and HIF-2 $\alpha$ was downloaded from PDB. HIF- $1 \alpha$ and HIF- $2 \alpha$ protein contain a bHLH region, a PAS region and an ODD domain. HIF, hypoxia inducible factor; bHLH, basic-helix-loop-helix; PAS, Per/Arnt/Sim; ODD, oxygen-dependent degradation; PDB, protein database. 


\section{HIF1}

NDRMAL

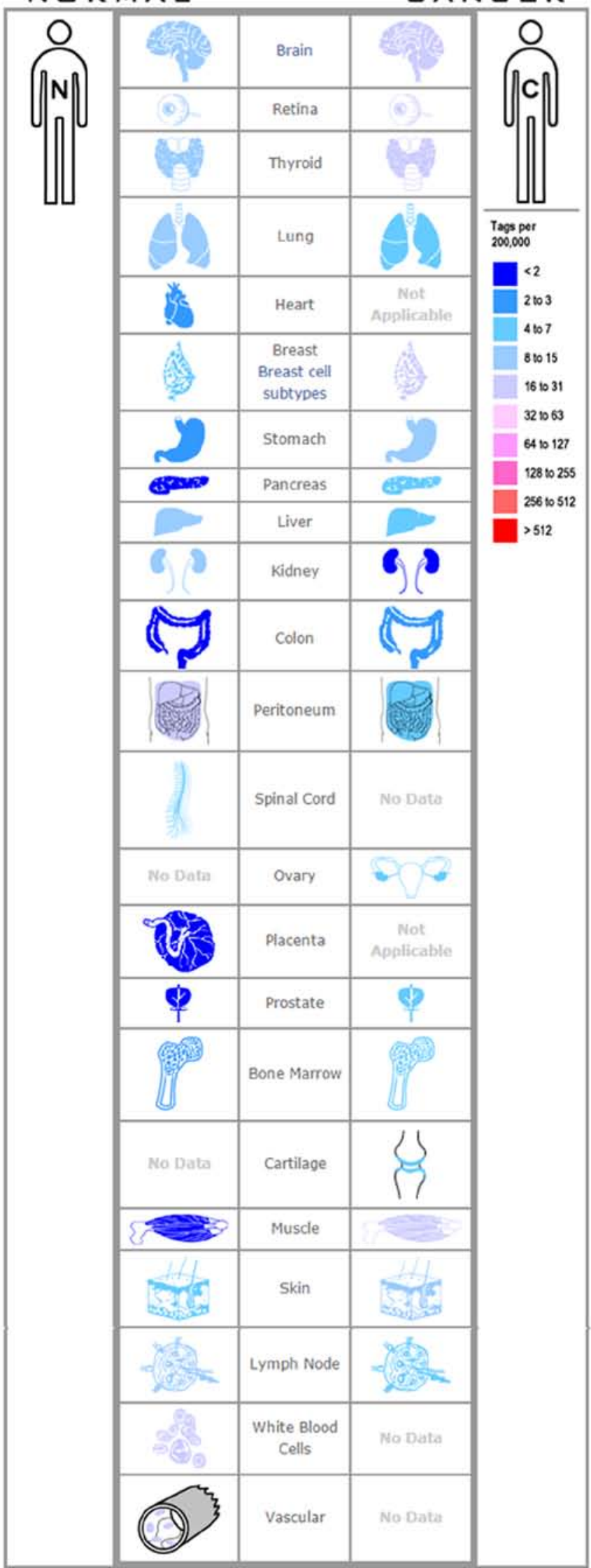

Figure 4. Expression profile for HIF-1 $\alpha$ in human cancers found by the SAGE DGED (http://www.ncbi.nlm.nih.gov/SAGE/). HIF-1 is expressed highly in the brain, thyroid, breast, pancreas, stomach and in prostate cancer. HIF, hypoxia inducible factor.
HIF2

N口RMAL

C A N C E R

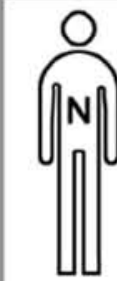

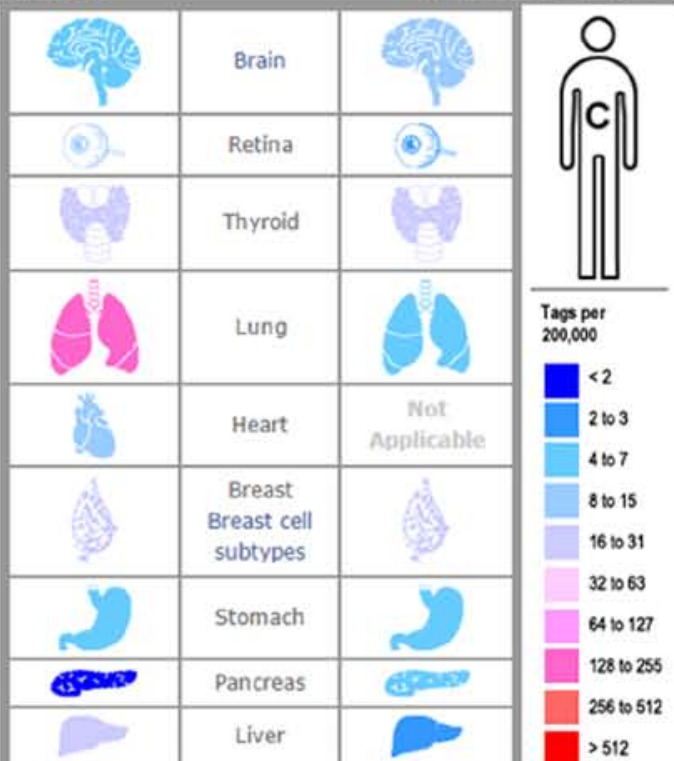

\begin{tabular}{|c|c|c|}
\hline & Kidney \\
\hline & Colon & \\
\hline & Peritoneum & \\
\hline
\end{tabular}

Figure 5. Expression profile for HIF-2 $\alpha$ in human cancers found by the SAGE DGED (http://www.ncbi.nlm.nih.gov/SAGE/). HIF-2 expressed highly in brain, pancreas, and stomach cancer. HIF, hypoxia inducible factor. 

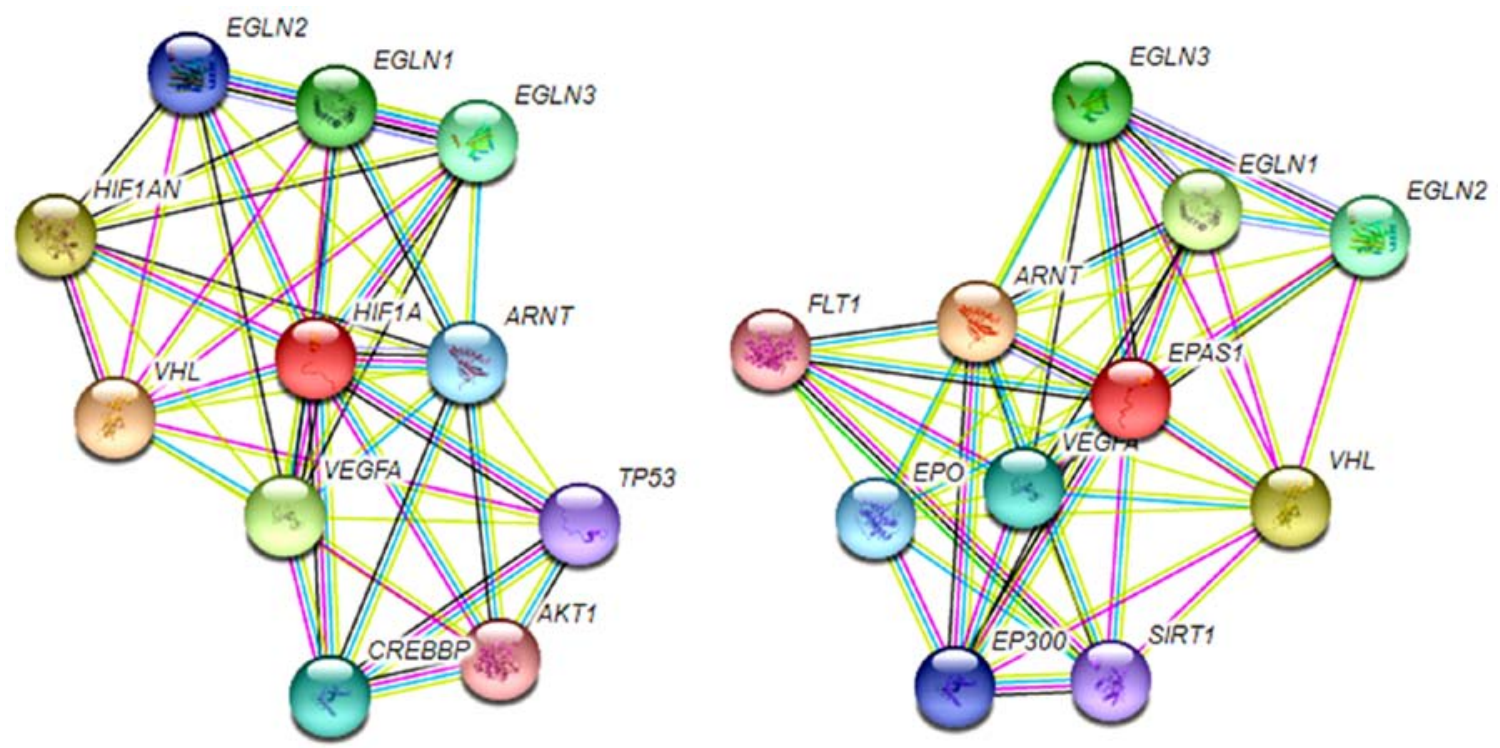

Figure 6. Interaction genes of HIF-1 $\alpha$ and HIF-2 $\alpha$ were analyzed using STRING (https://string-db.org/cgi/input.pl). HIF-1 $\alpha$ could interact with EGLN1-3, AKT1, TP53, and VHL. HIF-2 $\alpha$ could interact with EGLN1-3, EPO, SIRT1, and VHL. HIF, hypoxia inducible factor.

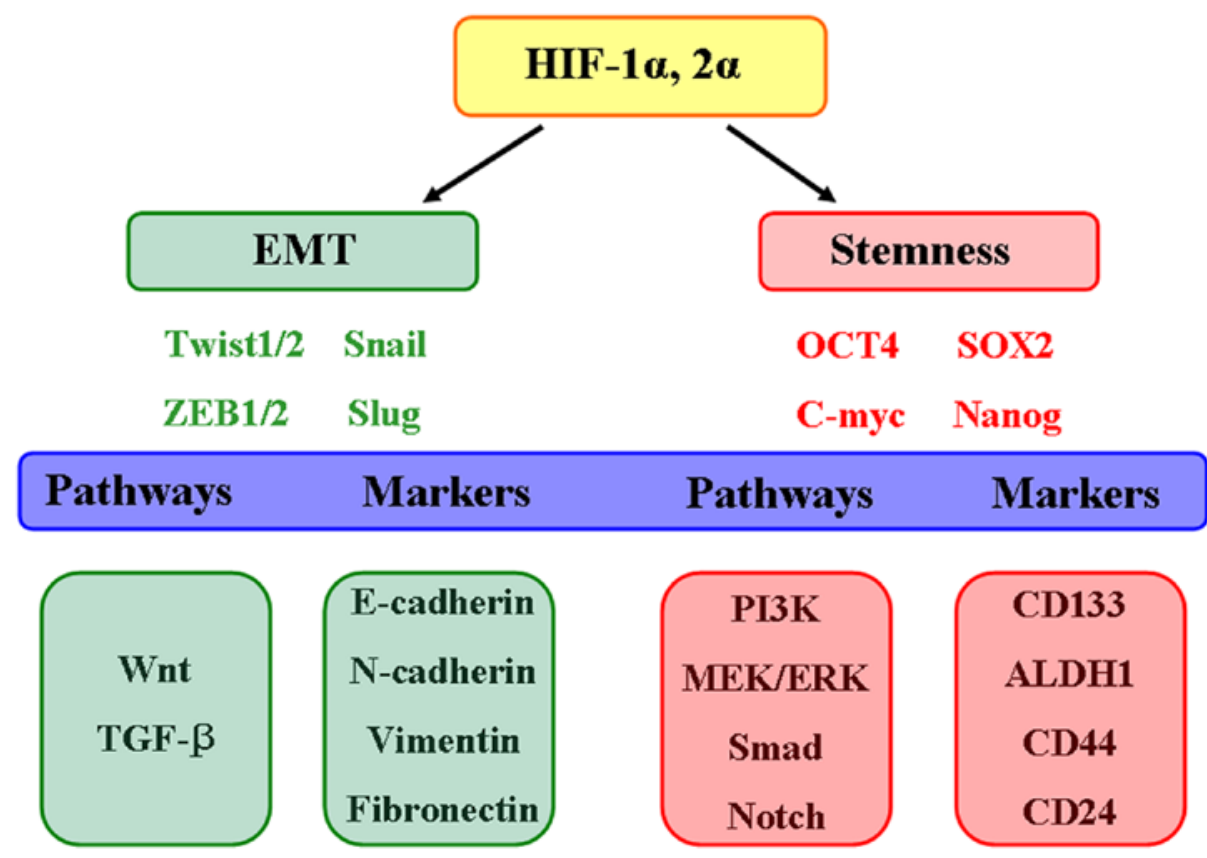

Figure 7. HIF-1 $\alpha$ and HIF-2 $\alpha$ in the driver seat of tumorigenesis. HIF, hypoxia inducible factor.

nucleus and bind to their target genes, such as BNIP3, PGK1, HK1 and TP11 (Fig. 6) (65). The target genes participate in the proliferation, apoptosis, metabolism and invasion, as well in the and resistance of cancer cells to therapy (66-68).

Genetic polymorphisms of HIF-1 $\alpha$ or HIF- $2 \alpha$ in human cancers have been found in previous studies (69-74). The single nucleotide polymorphisms $1772 \mathrm{C} / \mathrm{T}$ (rs11549465) and 1790 G/A (rs11549467) have been shown to be significantly associated with the overall risk of developing lung, breast, oral, prostate, cervical and renal cancers (69). Frank et al (70) demonstrated a significant association between rs2057482 in HIF-1 $\alpha$ with the risk of rectal cancer. Guo et al (71) found that rs2057482 was associated with worse clinical outcomes of patients with hepatocellular carcinoma. Han et al (72) observed that rs9679290, rs4953346 and rs12617313 of HIF-2 $\alpha$ were associated with the risk of developing renal cell carcinoma. Yamamoto et al (73) reported that HIF-2 $\alpha$ rs13419896 was associated with a decreased risk of developing lung cancer. HIF2A rs11125070 and rs4953352 are associated with the disease-free and overall survival of patients with colorectal cancer (74).

A non-coding RNA (ncRNA) is a functional RNA molecule that is not translated into a protein (75). miRNAs are the perfect candidates for controlling HIF expression during hypoxia (76). These so-called hypoxamiRs contribute to HIF-1 accumulation and the maintenance of HIF-2 and 
HIF-3 (77,78). For example, the hypoxic induction of miR-18a may allow HIF-1 $\alpha$ level decreases and thus contribute to the HIF switch (79). miR-17, miR-20a and miR-20b have been reported to be involved in the HIF-related response during hypoxia in cancer cells (80). IncRNA HIF-1A-AS2 negatively regulates HIF-1 $\alpha$ and is upregulated in non-papillary clear cell renal carcinomas (81). lncRNA sONE or NOS3AS regulates the expression of endothelial nitric oxide synthase (eNOS), under normal oxygen conditions and hypoxic conditions (82).

\section{The roles of HIFs in CSCs}

Increasing evidence indicates that HIFs regulate the subpopulations of CSCs $(83,84)$. The activation of HIF-1 $\alpha$ not only increases the number of cluster of differentiation (CD)133positive glioma stem cells, but also enhances the stem-like phenotype of cell lines (85). CSCs within several brain tumors are preferentially located in hypoxic niches (86). HIFs induce the self-renewal capacity and inhibit the differentiation of glioblastoma CSCs (87). The impact of hypoxia is mediated by HIF- $1 \alpha$, but not by HIF- $2 \alpha$, and is associated with the induction of the Hippo signaling pathway in breast CSCs (88). One key regulator of BCSC activity is a Hippo pathway effector, TAZ, which is a direct target of HIF-1 $\alpha$ (89). HIF activity can promote a stem-like phenotype and increase the number of leukemia stem cells (90). In AML, HIF-1 $\alpha$ is overexpressed and selectively activated in $\mathrm{CD} 34^{+} \mathrm{CD} 38^{-}$subsets (91). In lung cancer, hypoxia-induced CD133 expression is associated with the binding of OCT4 and SOX2 to the PROM1 promoter (92). The targeting of HIF- $1 \alpha$ or HIF- $2 \alpha$ by short hairpin RNA in $\mathrm{CD}_{133^{+}}$cells from a patient with glioblastoma inhibited their neurosphere-forming ability and proliferation, induced the caspase-dependent apoptotic effect in vitro and attenuated their tumor-initiating potential in vivo (93). The expression of CD44 and Oct4 stem cell markers is decreased in colorectal cancer cells in response to HIF-1 $\alpha$ knockdown (94). CD24 expression is strongly induced by hypoxia in a human bladder cancer cell line (95). In addition, combined HIF-1 $\alpha$ and CD24 immunostaining in human urothelial cancer samples showed a statistically significant association (95). HIF-2 $\alpha$ expression stimulates Oct-4 expression and promotes c-Myc activity, which powerfully impact cancer stem cell formation (96). HIF- $2 \alpha$ mRNA is significantly transcriptionally upregulated under normoxia and hypoxia in glioma stem cells (GSCs) (97).

\section{Future perspectives}

Hypoxia has notable potential to exert significant effects on the maintenance and evolution of CSCs. Both HIF-1 $\alpha$ and HIF- $2 \alpha$ contribute to the regulation of cellular adaptation to hypoxia and the resistance to cancer therapies (Fig. 7). The simultaneous targeting of the HIF- $1 \alpha$ and HIF- $2 \alpha$ pathways may improve clinical responses within the hypoxic tumor microenvironment. Therefore, the concept of personalized medicine should be applied in designing clinical trials for HIF inhibitors.

\section{Acknowledgements}

Not applicable.

\section{Funding}

No funding was received.

\section{Availability of data and materials}

Not applicable.

\section{Authors' contributions}

WWT and YL conceived the study. WWT and GHT collected the data and wrote the manuscript; WWT prepared the figures and revised the manuscript. All authors have read and approved the final manuscript.

\section{Ethics approval and consent to participate}

Not applicable.

\section{Consent for publication}

Not applicable.

\section{Competing Interests}

The authors declare that they have no competing interests.

\section{References}

1. Soni S and Padwad YS: HIF-1 in cancer therapy: Two decade long story of a transcription factor. Acta Oncol 56: 503-515, 2017.

2. Furth J and Kahn M: The transmission of leukemia of mice with a single cell. Am J Cancer 31: 276-282, 1937.

3. Southam CM and Brunschwig A: Quantitative studies of autotransplantation of human cancer. Cancer 14: 971-978, 1961.

4. Hamburger AW and Salmon SE: Primary bioassay of human tumor stem cells. Science 197: 461-463, 1977.

5. Lapidot T, Sirard C, Vormoor J, Murdoch B, Hoang T, CaceresCortes J, Minden M, Paterson B, Caligiuri MA and Dick JE: A cell initiating human acute myeloid leukaemia after transplantation into SCID mice. Nature 367: 645-648, 1994.

6. Bonnet D and Dick JE: Human acute myeloid leukemia is organized as a hierarchy that originates from a primitive hematopoietic cell. Nat Med 3: 730-737, 1997.

7. Al-Hajj M, Wicha MS, Benito-Hernandez A, Morrison SJ and Clarke MF: Prospective identification of tumorigenic breast cancer cells. Proc Natl Acad Sci USA 100: 3983-3988, 2003.

8. Singh SK, Hawkins C, Clarke ID, Squire JA, Bayani J, Hide T, Henkelman RM, Cusimano MD and Dirks PB: Identification of human brain tumour initiating cells. Nature 432: 396-401, 2004.

9. Ponti D, Costa A, Zaffaroni N, Pratesi G, Petrangolini G, Coradini D, Pilotti S, Pierotti MA and Daidone MG: Isolation and in vitro propagation of tumorigenic breast cancer cells with stem/progenitor cell properties. Cancer Res 65: 5506-5511, 2005.

10. Patrawala L, Calhoun T, Schneider-Broussard R, Li H, Bhatia B, Tang S, Reilly JG, Chandra D, Zhou J, Claypool K, et al: Highly purified $\mathrm{CD} 44^{+}$prostate cancer cells from xenograft human tumors are enriched in tumorigenic and metastatic progenitor cells. Oncogene 25: 1696-1708, 2006.

11. López J, Valdez-Morales FJ, Benítez-Bribiesca L, Cerbón M and Carrancá AG: Normal and cancer stem cells of the human female reproductive system. Reprod Biol Endocrinol 11: 53, 2013.

12. Takahashi $\mathrm{K}$ and Yamanaka S: Induction of pluripotent stem cells from mouse embryonic and adult fibroblast cultures by defined factors. Cell 126: 663-676, 2006.

13. Ohnishi K, Semi K, Yamamoto T, Shimizu M, Tanaka A, Mitsunaga K, Okita K, Osafune K, Arioka Y, Maeda T, et al: Premature termination of reprogramming in vivo leads to cancer development through altered epigenetic regulation. Cell 156: 663-677, 2014. 
14. Beck B and Blanpain C: Unravelling cancer stem cell potential. Nat Rev Cancer 13: 727-738, 2013.

15. Wang RA, Li ZS, Zhang HZ, Zheng PJ, Li QL, Shi JG, Yan QG, Ye $\mathrm{J}$, Wang JB, Guo Y, et al: Invasive cancers are not necessarily from preformed in situ tumours - an alternative way of carcinogenesis from misplaced stem cells. J Cell Mol Med 17: 921-926, 2013.

16. Clarke MF, Dick JE, Dirks PB, Eaves CJ, Jamieson CH, Jones DL, Visvader J, Weissman IL and Wahl GM: Cancer stem cells - perspectives on current status and future directions: AACR Workshop on cancer stem cells. Cancer Res 66: 9339-9344, 2006.

17. Reya T, Morrison SJ, Clarke MF and Weissman IL: Stem cells, cancer, and cancer stem cells. Nature 414: 105-111, 2001.

18. Cabrera MC, Hollingsworth RE and Hurt EM: Cancer stem cell plasticity and tumor hierarchy. World J Stem Cells 7: 27-36, 2015.

19. Kuroda T, Yasuda S and Sato Y: Tumorigenicity studies for human pluripotent stem cell-derived products. Biol Pharm Bull 36: 189-192, 2013

20. Adorno-Cruz V, Kibria G, Liu X, Doherty M, Junk DJ, Guan D, Hubert C, Venere M, Mulkearns-Hubert E, Sinyuk M, et al: Cancer stem cells: Targeting the roots of cancer, seeds of metastasis, and sources of therapy resistance. Cancer Res 75: 924-929, 2015

21. O'Brien CA, Pollett A, Gallinger S and Dick JE: A human colon cancer cell capable of initiating tumour growth in immunodeficient mice. Nature 445: 106-110, 2007.

22. Hope KJ, Jin L and Dick JE: Acute myeloid leukemia originates from a hierarchy of leukemic stem cell classes that differ in selfrenewal capacity. Nat Immunol 5: 738-743, 2004

23. Xia P, Gou WF, Zhao S and Zheng HC: Crizotinib may be used in Lewis lung carcinoma: A novel use for crizotinib. Oncol Rep 30: 139-148, 2013

24. Vescovi AL, Galli R and Reynolds BA: Brain tumour stem cells Nat Rev Cancer 6: 425-436, 2006.

25. Vargo-Gogola T and Rosen JM: Modelling breast cancer: One size does not fit all. Nat Rev Cancer 7: 659-672, 2007.

26. Tsai RY: Balancing self-renewal against genome preservation in stem cells: How do they manage to have the cake and eat it too? Cell Mol Life Sci 73: 1803-1823, 2016.

27. Huntly BJ and Gilliland DG: Leukaemia stem cells and the evolution of cancer-stem-cell research. Nat Rev Cancer 5 : 311-321, 2005

28. Daynac M and Petritsch CK: Regulation of asymmetric cell division in mammalian neural stem and cancer precursor cells. Results Probl Cell Differ 61: 375-399, 2017.

29. Wang L, Bu P and Shen X: Asymmetric division: An antitumor player? Mol Cell Oncol 3: e1164279, 2016.

30. Wu L, Wang G, Liu S, Wei J, Zhang S, Li M, Zhou G and Wang L: Synthesis and biological evaluation of matrine derivatives containing benzo- $\alpha$-pyrone structure as potent anti-lung cancer agents. Sci Rep 6: 35918, 2016

31. Ait-Oudhia S and Mager DE: Array of translational systems pharmacodynamic models of anti-cancer drugs. J Pharmacokinet Pharmacodyn 43: 549-565, 2016.

32. O'Connor R, Clynes M, Dowling P, O'Donovan $\mathrm{N}$ and O'Driscoll $\approx$ L: Drug resistance in cancer - searching for mechanisms, markers and therapeutic agents. Expert Opin Drug Metab Toxicol 3: 805-817, 2007.

33. Yu Z, Pestell TG, Lisanti MP and Pestell RG: Cancer stem cells. Int J Biochem Cell Biol 44: 2144-2151, 2012.

34. Gottesman MM, Fojo T and Bates SE: Multidrug resistance in cancer: Role of ATP-dependent transporters. Nat Rev Cancer 2 48-58, 2002.

35. Ramachandra M, Ambudkar SV, Chen D, Hrycyna CA, Dey S, Gottesman MM and Pastan I: Human P-glycoprotein exhibits reduced affinity for substrates during a catalytic transition state. Biochemistry 37: 5010-5019, 1998.

36. Dean M, Hamon Y and Chimini G: The human ATP-binding cassette (ABC) transporter superfamily. J Lipid Res 42: $1007-1017,2001$

37. Kort A, van Hoppe S, Sparidans RW, Wagenaar E, Beijnen JH and Schinkel AH: Brain accumulation of ponatinib and its active metabolite, N-desmethyl ponatinib, is limited by P-glycoprotein (P-GP/ABCB1) and breast cancer resistance protein (BCRP/ ABCG2). Mol Pharm 14: 3258-3268, 2017.

38. Eckford PD and Sharom FJ: ABC efflux pump-based resistance to chemotherapy drugs. Chem Rev 109: 2989-3011, 2009.

39. Trock BJ, Leonessa F and Clarke R: Multidrug resistance in breast cancer: A meta-analysis of MDR1/gp170 expression and its possible functional significance. J Natl Cancer Inst 89: 917-931, 1997
40. Zhou DC, Zittoun R and Marie JP: Expression of multidrug resistance-associated protein (MRP) and multidrug resistance (MDR1) genes in acute myeloid leukemia. Leukemia 9: 1661-1666, 1995

41. Grogan TM, Spier CM, Salmon SE, Matzner M, Rybski J, Weinstein RS, Scheper RJ and Dalton WS: P-glycoprotein expression in human plasma cell myeloma: Correlation with prior chemotherapy. Blood 81: 490-495, 1993

42. Chan HS, Grogan TM, Haddad G, DeBoer G and Ling V: P-glycoprotein expression: Critical determinant in the response to osteosarcoma chemotherapy. J Natl Cancer Inst 89: 1706-1715, 1997.

43. Gillet JP and Gottesman MM: Mechanisms of multidrug resistance in cancer. Methods Mol Biol 596: 47-76, 2010.

44. Leslie EM, Deeley RG and Cole SP: Multidrug resistance proteins: Role of P-glycoprotein, MRP1, MRP2, and BCRP (ABCG2) in tissue defense. Toxicol Appl Pharmacol 204: 216-237, 2005.

45. Rohwer $\mathrm{N}$ and Cramer T: Hypoxia-mediated drug resistance: Novel insights on the functional interaction of HIFs and cell death pathways. Drug Resist Updat 14: 191-201, 2011.

46. da Costa KM, Valente RC, Salustiano EJ, Gentile LB, Freire-de-Lima L, Mendonça-Previato L and Previato JO: Functional Characterization of ABCC proteins from trypanosoma cruzi and their involvement with thiol transport. Front Microbiol 9: 205, 2018.

47. Yin JY, Han LF, Huang Q, Xu XJ, Zhou HH and Liu ZQ: ABCC1 polymorphism Arg723Gln $(2168 \mathrm{G}>\mathrm{A})$ is associated with lung cancer susceptibility in a Chinese population. Clin Exp Pharmacol Physiol 38: 632-637, 2011.

48. Arumugam P and Song JM: Quantitative evaluation of ABC transporter-mediated drug resistance based on the determination of the anticancer activity of camptothecin against breast cancer stem cells using TIRF. Integr Biol 8: 704-711, 2016.

49. Liu C, Li Z, Bi L, Li K, Zhou B, Xu C, Huang J and Xu K: NOTCH1 signaling promotes chemoresistance via regulating ABCC1 expression in prostate cancer stem cells. Mol Cell Biochem 393: 265-270, 2014

50. Johnson ZL and Chen J: ATP binding enables substrate release from multidrug resistance protein 1. Cell 172: 81-89.e10, 2018.

51. Castilho L and Reid ME: A review of the JR blood group system. Immunohematology 29: 63-68, 2013.

52. Fujita $\mathrm{K}$ and Ichida K: ABCG2 as a therapeutic target candidate for gout. Expert Opin Ther Targets 22: 123-129, 2018.

53. D'Ignazio L, Batie $M$ and Rocha S: Hypoxia and inflammation in cancer, focus on HIF and NF-кB. Biomedicines 5: E21, 2017.

54. Zhang P, Yao Q, Lu L, Li Y, Chen PJ and Duan C: Hypoxiainducible factor 3 is an oxygen-dependent transcription activator and regulates a distinct transcriptional response to hypoxia. Cell Reports 6: 1110-1121, 2014.

55. Wang GL, Jiang BH, Rue EA and Semenza GL: Hypoxiainducible factor 1 is a basic-helix-loop-helix-PAS heterodimer regulated by cellular O2 tension. Proc Natl Acad Sci USA 92: 5510-5514, 1995

56. Kallio PJ, Okamoto K, O'Brien S, Carrero P, Makino Y, Tanaka $\mathrm{H}$ and Poellinger L: Signal transduction in hypoxic cells: Inducible nuclear translocation and recruitment of the CBP/p300 coactivator by the hypoxia-inducible factor-1alpha. EMBO J 17: 6573-6586, 1998 .

57. Dayan F, Roux D, Brahimi-Horn MC, Pouyssegur J and Mazure NM: The oxygen sensor factor-inhibiting hypoxiainducible factor- 1 controls expression of distinct genes through the bifunctional transcriptional character of hypoxia-inducible factor-1alpha. Cancer Res 66: 3688-3698, 2006.

58. Jiang BH, Semenza GL, Bauer C and Marti HH: Hypoxia-inducible factor 1 levels vary exponentially over a physiologically relevant range of $\mathrm{O} 2$ tension. Am J Physiol 271: C1172-C1180, 1996.

59. Hu CJ, Sataur A, Wang L, Chen $\mathrm{H}$ and Simon MC: The $\mathrm{N}$-terminal transactivation domain confers target gene specificity of hypoxia-inducible factors HIF-1alpha and HIF-2alpha. Mol Biol Cell 18: 4528-4542, 2007.

60. Badowska-Kozakiewicz AM, Sobol M and Patera J: Expression of multidrug resistance protein P-glycoprotein in correlation with markers of hypoxia (HIF-1 $\alpha$, EPO, EPO-R) in invasive breast cancer with metastasis to lymph nodes. Arch Med Sci 13: 1303-1314, 2017

61. Rodríguez ME, Catrinacio C, Ropolo A, Rivarola VA and Vaccaro MI: A novel HIF-1 $\alpha /$ VMP1-autophagic pathway induces resistance to photodynamic therapy in colon cancer cells. Photochem Photobiol Sci 16: 1631-1642, 2017. 
62. Shao JS, Sun J, Wang S, Chung K, Du JT, Wang J, Qiu XS Wang EH and Wu GP: HPV16 E6/E7 upregulates HIF-2 $\alpha$ and VEGF by inhibiting LKB1 in lung cancer cells. Tumour Biol 39: 1010428317717137, 2017.

63. Zhang Q, Lou Y, Zhang J, Fu Q, Wei T, Sun X, Chen Q, Yang J, Bai X and Liang T: Hypoxia-inducible factor- $2 \alpha$ promotes tumor progression and has crosstalk with Wnt $/ \beta$-catenin signaling in pancreatic cancer. Mol Cancer 16: 119, 2017.

64. Raspaglio G, Petrillo M, Martinelli E, Li Puma DD, Mariani M, De Donato M, Filippetti F, Mozzetti S, Prislei S, Zannoni GF et al: Sox 9 and Hif- $2 \alpha$ regulate TUBB3 gene expression and affect ovarian cancer aggressiveness. Gene 542: 173-181, 2014.

65. Jun JC, Rathore A, Younas H, Gilkes D and Polotsky VY: Hypoxia-Inducible Factors and Cancer. Curr Sleep Med Rep 3 . 1-10, 2017.

66. Vandyke K, Zeissig MN, Hewett DR, Martin SK, Mrozik KM, Cheong CM, Diamond P, To LB, Gronthos S, Peet DJ, et al: HIF- $2 \alpha$ promotes dissemination of plasma cells in multiple myeloma by regulating CXCL12/CXCR4 and CCR1. Cancer Res 77: 5452-5463, 2017.

67. Ma X, Zhang H, Xue X and Shah YM: Hypoxia-inducible factor $2 \alpha(\mathrm{HIF}-2 \alpha)$ promotes colon cancer growth by potentiating Yes-associated protein 1 (YAP1) activity. J Biol Chem 292: 17046-17056, 2017.

68. Garziera M, Scarabel L and Toffoli G: Hypoxic modulation of HLA-G expression through the metabolic sensor HIF-1 in human cancer cells. J Immunol Res 2017: 4587520, 2017.

69. Anam MT, Ishika A, Hossain MB and Jesmin : A meta-analysis of hypoxia inducible factor 1-alpha (HIF1A) gene polymorphisms: Association with cancers. Biomark Res 3: 29, 2015

70. Frank B, Hoffmeister M, Klopp N, Illig T, Chang-Claude J and Brenner H: Single nucleotide polymorphisms in Wnt signaling and cell death pathway genes and susceptibility to colorectal cancer. Carcinogenesis 31: 1381-1386, 2010.

71. Guo X, Li D, Chen Y, An J, Wang K, Xu Z, Chen Z and Xing J: SNP rs2057482 in HIF1A gene predicts clinical outcome of aggressive hepatocellular carcinoma patients after surgery. Sci Rep 5: 11846, 2015.

72. Han SS, Yeager M, Moore LE, Wei MH, Pfeiffer R, Toure O, Purdue MP, Johansson M, Scelo G, Chung CC, et al: The chromosome 2 p21 region harbors a complex genetic architecture for association with risk for renal cell carcinoma. Hum Mol Genet 21: 1190-1200, 2012.

73. Yamamoto Y, Kiyohara C, Ogata-Suetsugu S, Hamada N and Nakanishi Y: Association between genetic polymorphisms involved in the hypoxia-inducible factor pathway and lung cancer risk: A case-control study in Japan. Asia Pac J Clin Oncol 13 234-242, 2017

74. Haja Mohideen AM, Hyde A, Squires J, Wang J, Dicks E, Younghusband B, Parfrey P, Green R and Savas S: Examining the polymorphisms in the hypoxia pathway genes in relation to outcome in colorectal cancer. PLoS One 9: e113513, 2014.

75. Autour A, C Y Jeng S, D Cawte A, Abdolahzadeh A, Galli A Panchapakesan SSS, Rueda D, Ryckelynck M and Unrau PJ Fluorogenic RNA Mango aptamers for imaging small noncoding RNAs in mammalian cells. Nat Commun 9: 656, 2018.

76. Camps C, Saini HK, Mole DR, Choudhry H, Reczko M, GuerraAssunção JA, Tian YM, Buffa FM, Harris AL, Hatzigeorgiou AG, et al: Integrated analysis of microRNA and mRNA expression and association with HIF binding reveals the complexity of microRNA expression regulation under hypoxia. Mol Cancer 13 28,2014

77. Ho JJ, Metcalf JL, Yan MS, Turgeon PJ, Wang JJ, Chalsev M, Petruzziello-Pellegrini TN, Tsui AK, He JZ, Dhamko H, et al: Functional importance of Dicer protein in the adaptive cellula response to hypoxia. J Biol Chem 287: 29003-29020, 2012.

78. van den Beucken T, Koch E, Chu K, Rupaimoole R, Prickaerts P, Adriaens M, Voncken JW, Harris AL, Buffa FM, Haider S, et al Hypoxia promotes stem cell phenotypes and poor prognosis through epigenetic regulation of DICER. Nat Commun 5: 5203 , 2014.
79. Montoya MM, Maul J, Singh PB, Pua HH, Dahlström F, Wu N, Huang X, Ansel KM and Baumjohann D: A distinct inhibitory function for miR-18a in Th17 cell differentiation. J Immunol 199: 559-569, 2017.

80. Li JY, Zhang Y, Zhang WH, Jia S, Kang Y and Zhu XY: Differential distribution of miR-20a and miR-20b may underly metastatic heterogeneity of breast cancers. Asian Pac J Cancer Prev 13: 1901-1906, 2012.

81. Kunej T, Obsteter J, Pogacar Z, Horvat S and Calin GA: The decalog of long non-coding RNA involvement in cancer diagnosis and monitoring. Crit Rev Clin Lab Sci 51: 344-357, 2014.

82. Im JH and Muschel RJ: New evidence of lncRNA role in tumor progression and metastasis. Hepatobiliary Surg Nutr 1: 55-56, 2012.

83. Schito L and Semenza GL: Hypoxia-inducible factors: Master regulators of cancer progression. Trends Cancer 2: 758-770, 2016.

84. Mohlin S, Wigerup C, Jögi A and Påhlman S: Hypoxia, pseudohypoxia and cellular differentiation. Exp Cell Res 356: 192-196, 2017.

85. Shi QY, Zhang SJ, Liu L, Chen QS, Yu LN, Zhang FJ and Yan M: Sevoflurane promotes the expansion of glioma stem cells through activation of hypoxia-inducible factors in vitro. Br J Anaesth 114: 825-830, 2015 .

86. Lee G, Auffinger B, Guo D, Hasan T, Deheeger M, Tobias AL, Kim JY, Atashi F, Zhang L, Lesniak MS, et al: Dedifferentiation of glioma cells to glioma stem-like cells by therapeutic stress-induced HIF signaling in the recurrent GBM model. Mol Cancer Ther 15: 3064-3076, 2016.

87. Zhang S, Luo X, Wan F and Lei T: The roles of hypoxia-inducible factors in regulating neural stem cells migration to glioma stem cells and determinating their fates. Neurochem Res 37 2659-2666, 2012

88. Semenza GL: Regulation of the breast cancer stem cell phenotype by hypoxia-inducible factors. Clin Sci (Lond) 129: 1037-1045, 2015.

89. Samanta D, Gilkes DM, Chaturvedi P, Xiang L and Semenza GL: Hypoxia-inducible factors are required for chemotherapy resistance of breast cancer stem cells. Proc Natl Acad Sci USA 111: E5429-E5438, 2014.

90. Deynoux M, Sunter N, Hérault O and Mazurier F: Hypoxia and hypoxia-inducible factors in leukemias. Front Oncol 6: 41, 2016.

91. Heddleston JM, Wu Q, Rivera M, Minhas S, Lathia JD, Sloan AE, Iliopoulos O, Hjelmeland AB and Rich JN: Hypoxiainduced mixed-lineage leukemia 1 regulates glioma stem cell tumorigenic potential. Cell Death Differ 19: 428-439, 2012.

92. Sun JC, He F, Yi W, Wan MH, Li R, Wei X, Wu R and Niu DL: High expression of HIF-2 $\alpha$ and its anti-radiotherapy effect in lung cancer stem cells. Genet Mol Res 14: 18110-18120, 2015

93. Dhatwalia SK, Kumar M and Dhawan DK: Role of EGCG in containing the progression of lung tumorigenesis - A multistage targeting approach. Nutr Cancer 70: 334-349, 2018.

94. Vadde R, Vemula S, Jinka R, Merchant N, Bramhachari PV and Nagaraju GP: Role of hypoxia-inducible factors (HIF) in the maintenance of stemness and malignancy of colorectal cancer. Crit Rev Oncol Hematol 113: 22-27, 2017.

95. Thomas S, Harding MA, Smith SC, Overdevest JB, Nitz MD, Frierson HF, Tomlins SA, Kristiansen G and Theodorescu D: CD24 is an effector of HIF-1-driven primary tumor growth and metastasis. Cancer Res 72: 5600-5612, 2012.

96. Bhagat M, Palanichamy JK, Ramalingam P, Mudassir M, Irshad K, Chosdol K, Sarkar C, Seth P, Goswami S, Sinha S, et al: HIF- $2 \alpha$ mediates a marked increase in migration and stemness characteristics in a subset of glioma cells under hypoxia by activating an Oct-4/Sox-2-Mena (INV) axis. Int J Biochem Cell Biol 74: 60-71, 2016.

97. Johansson E, Grassi ES, Pantazopoulou V, Tong B, Lindgren D, Berg TJ, Pietras EJ, Axelson $\mathrm{H}$ and Pietras A: CD44 interacts with HIF- $2 \alpha$ to modulate the hypoxic phenotype of perinecrotic and perivascular glioma cells. Cell Reports 20: 1641-1653, 2017. 